Article

\title{
Back from the Past: DNA Barcodes and Morphology Support Ablabesmyia americana Fittkau as a Valid Species (Diptera: Chironomidae)
}

\author{
Elisabeth Stur ${ }^{1, *}$, Fabio Laurindo da Silva ${ }^{1,2}$ and Torbjørn Ekrem ${ }^{1}$ (D) \\ 1 Department of Natural History, NTNU University Museum, Norwegian University of Science and \\ Technology, NO-7491 Trondheim, Norway; fabiologia@gmail.com (F.L.d.S.); torbjorn.ekrem@ntnu.no (T.E.) \\ 2 Department of Zoology, Institute of Biosciences, University of São Paulo, São Paulo 05508-090, Brazil \\ * Correspondence: elisabeth.stur@ntnu.no; Tel.: +47-73592297
}

Received: 9 August 2019; Accepted: 17 September 2019; Published: 19 September 2019

check for updates

\begin{abstract}
Short, standardized gene fragments for species identification (DNA barcodes) have proven effective in delineating closely-related insect species, and can be critical characters to include in taxonomic studies. This is also the case for the species-rich and widely distributed fly family Chironomidae (non-biting midges). Inspired by observed genetic differences in partial COI gene sequences between North American and European populations of the chironomid Ablabesmyia monilis sensu lato, we investigated whether or not the morphology of male and female adults supported the distinction of more than one species. Our results support that the junior synonym Ablabesmyia americana is a valid species separate from $A$. monilis, and that $A$. monilis sensu stricto is distributed both in the Palearctic region and in North America. We provide re-descriptions of all of the major life stages of A. americana and of the adult female of $A$. monilis.
\end{abstract}

Keywords: DNA barcodes; taxonomy; species delimitation; synonymy; Tanypodinae

\section{Introduction}

Over the last ten years, molecular approaches to analyze species boundaries have seen rapid development. Genetic divergences in the partial cytochrome c oxidase subunit 1 (COI) sequences (so-called DNA barcodes [1]) have proven effective for species recognition in several animal groups, including non-biting midges belonging to the family Chironomidae (Insecta, Diptera) (e.g., [2-6]). In several cases, DNA barcodes have also aided the detection of presumably cryptic species, whose distinction a posteriori could be confirmed by both morphology and nuclear genetic markers (e.g., $[7,8])$. Furthermore, DNA barcodes have been shown suitable to associate life stages in the family Chironomidae [9-11].

Ablabesmyia is a large and ecologically diverse genus in the subfamily Tanypodinae. About 90 species are known worldwide ([12] and citations within), many of them described from the Neotropical Region [13]. These small to medium size dipterans $(1.00-6.00 \mathrm{~mm})$ are found in a broad range of aquatic systems, from small streams and ponds to lakes and rivers. Larvae can live in freshwater sponge colonies [14]. The genus was erected by Johannsen [15] with Tipula monilis Linnaeus, 1758, as the type species. Historically Ablabesmyia had a wider concept, with most of its members placed in the Pentaneura group A of Edwards [16] and Johannsen [17]. Later, Freeman [18] and Roback [19] relegated Ablabesmyia to subgeneric status in Pentaneura (Philippi, 1865), while Fittkau [20] gave it full generic status. Ablabesmyia larvae are predators, and are recorded in many ecological studies (e.g., [21-24]). The genus is one of the most distinctive and well-defined genera within the tribe Pentaneurini, with adult males possessing a homologous complex of dorsomedial blades and lobes in their genitalia unique to the taxon $[25,26]$. 
The genus Ablabesmyia comprises four valid subgenera: Ablabesmyia Johannsen, Asayia Roback, Karelia Roback and Sartaia Roback. However, Oliveira, Silva and Gessner [13] reported inconsistencies in the establishment of these subgroups, and suggested at least one additional subgenus for Ablabesmyia, without promoting this taxonomic action. Identification of the adult Ablabesmyia is primarily based on features of the genitalia, as it is for many other members of Chironomidae. The morphological identification can be challenging, particularly for non-experts, and normally requires time-consuming dissections of the genitalia. In addition, some Ablabesmyia species lack diagnostic morphological traits in their adult life stage, and need associated larvae and pupae to be morphologically identifiable to species-level. Despite these obstacles, the taxonomy of Ablabesmyia has been investigated in multiple geographic regions, especially in the Neotropics (e.g., [13,14,27-31]), providing identification keys to species-level, as well as extensive reference collections. This makes Ablabesmyia a good model taxon to investigate the congruence between molecular and morphological traits.

Ablabesmyia americana was erected by Fittkau [20] as a species separate from A. monilis (Linnaeus, 1758) based on the inner features of the male genitalia, but without specifying the exact characters. Subsequently, Roback [25] compared North American with European specimens, and was unable to find any valid differences to justify the distinction of a separate species for the New World specimens, synonymizing A. americana with A. monilis. Through the sampling and DNA barcoding of $A$. monilis populations in North America and Europe, we discovered considerable genetic divergence across the northern Atlantic region. We were therefore inspired to investigate if this divergence could be supported by the morphology of larvae, pupae and adult life stages, and if the synonymy of Ablabesmyia americana and A. monilis can be supported.

\section{Materials and Methods}

The specimens included in this study were selected to represent taxa with a possible taxonomic conflict in the Ablabesmyia gr. monilis sensu Fittkau [20]. Fieldwork was conducted near and in the streams, rivers, fens, ponds and lakes of eastern, central and northern Norway, and Churchill, northern Canada (Manitoba). The material was initially collected for inventory studies and part of the International Barcode of Life initiative. Fourth-instar larvae and pupae were collected with hand nets, and adults sampled with sweep nets, emergence and Malaise traps. Specimens from Japan identified to A. monilis were kindly provided by Hiromi Niitsuma through Bohdan Bilyj. A small piece of tissue for DNA extraction was sampled under a stereomicroscope and sent to the Canadian Centre for DNA Barcoding at the University of Guelph (CCDB, www.dnabarcoding.ca) for DNA isolation, polymerase chain reaction (PCR) and sequencing. The remnants of nearly all of the sampled specimens were then macerated in potassium hydroxide $(\mathrm{KOH})$ and mounted on permanent microscope slides in Euparal for species identification with a compound microscope. Measurements were taken according to Epler [32]. Morphological terminology and abbreviations follow Roback [25] and Sæther [33], supplemented by Kowalyk [34] for larval cephalic setation (head hairiness) and Silva et al. [35,36] for larval terminology. One slide-mounted male and one slide mounted female specimen from the Johannsen collection out of Ithaca dated prior to his 1905 work were analyzed. Seven additional slides with larvae and two with females were also examined, but these either did not have their date or their locality written on the labels. Material from the Johannsen collection is deposited in the Cornell University Insect Collection, Ithaca, New York, USA (CUIC). Other examined material is deposited in the NTNU University Museum, Norwegian University of Science and Technology, Trondheim, Norway (NTNU-VM); or the Centre for Biodiversity Genomics, University of Guelph, Canada.

Sequence information along with an image and collateral information for each voucher specimen were entered into the Barcode of Life Data System (BOLD) [37]. The detailed specimen records and sequence information, including trace files, are available in BOLD through the dataset 'DS-ABLA, Ablabesmyia americana and A. monilis: A review' with doi: 10.5883/DS-ABLA. GenBank accessions are given in Table 1. 
Table 1. List of analyzed specimens with associated sample localities, Specimen IDs and GenBank accessions.

\begin{tabular}{|c|c|c|c|c|c|}
\hline Taxon & Country & Life Stage & BOLD ID & NTNU-VM & GB Accession \\
\hline Ablabesmyia americana & Canada & Adult & 10PROBE-11666 & & JF875917 \\
\hline Ablabesmyia americana & Canada & Adult & 10PROBE-12218 & & JF876334 \\
\hline Ablabesmyia americana & Canada & Adult & 10PROBE-12910 & & JF876913 \\
\hline Ablabesmyia americana & Canada & Adult & 10PROBE-16464 & & KR655494 \\
\hline Ablabesmyia americana & Canada & Male adult & CHIR_CH10 & 201777 & MK403766 \\
\hline Ablabesmyia americana & Canada & Male adult & CHIR_CH174 & 201778 & MK403744 \\
\hline Ablabesmyia americana & Canada & Male adult & CHIR_CH228 & 201779 & MK403740 \\
\hline Ablabesmyia americana & Canada & Male adult & CHIR_CH267 & 201780 & MK403767 \\
\hline Ablabesmyia americana & Canada & Female adult & CHIR_CH268 & 201781 & MK403747 \\
\hline Ablabesmyia americana & Canada & Male adult & CHIR_CH396 & 201782 & MK403752 \\
\hline Ablabesmyia americana & Canada & Male adult & HLC-27231 & 201785 & KR433631 \\
\hline Ablabesmyia americana & Canada & Female adult & HLC-27246 & 201786 & KR433665 \\
\hline Ablabesmyia americana & Canada & Male adult & HLC-27252 & 201790 & KR443910 \\
\hline Ablabesmyia aspera & Canada & Adult & 10PROBE-10650 & & JF875206 \\
\hline Ablabesmyia aspera & Canada & Adult & 10PROBE-11271 & & JF875757 \\
\hline Ablabesmyia aspera & Canada & Adult & 10PROBE-12725 & & JF876793 \\
\hline Ablabesmyia aspera & Canada & Adult & 10PROBE-12912 & & JF876915 \\
\hline Ablabesmyia aspera & Canada & Adult & 10PROBE-13831 & & KR668901 \\
\hline Ablabesmyia aspera & Norway & Male adult & ATNA539 & 201788 & MK403756 \\
\hline Ablabesmyia aspera & Norway & Male adult & CH-OSF172 & 143691 & JN285991 \\
\hline Ablabesmyia aspera & Norway & Male adult & $\mathrm{CH}-\mathrm{OSF} 174$ & 143693 & MK403755 \\
\hline Ablabesmyia aspera & Canada & Male adult & CHIR_CH638 & 201783 & MK403753 \\
\hline Ablabesmyia aspera & Canada & Male adult & HLC-27096 & 201784 & KR435725 \\
\hline Ablabesmyia aspera & Norway & Female adult & SOE94 & 124714 & HQ105015 \\
\hline Ablabesmyia longistyla & Norway & Male adult & TRD-CH185 & 200177 & MK403739 \\
\hline Ablabesmyia monilis & Norway & Female adult & ATNA330 & 201789 & HM421433 \\
\hline Ablabesmyia monilis & Norway & Female adult & ATNA538 & 201787 & MK403749 \\
\hline Ablabesmyia monilis & Japan & Female adult & ES358 & 201791 & MK403757 \\
\hline Ablabesmyia monilis & Japan & Male adult & ES360 & 201793 & MK403737 \\
\hline Ablabesmyia monilis & Japan & Male adult & ES361 & 201794 & MK403738 \\
\hline Ablabesmyia monilis & Norway & Male adult & Finnmark213 & 136311 & JF870860 \\
\hline Ablabesmyia monilis & Norway & Male adult & Finnmark214 & 136312 & JF870861 \\
\hline Ablabesmyia monilis & Norway & Male adult & Finnmark258 & 136355 & JN285993 \\
\hline Ablabesmyia monilis & Norway & Male adult & Finnmark 458 & 136554 & JN286007 \\
\hline Ablabesmyia monilis & Norway & Male adult & Finnmark508 & 136603 & JN286012 \\
\hline Ablabesmyia monilis & Norway & Male adult & Finnmark568 & 136663 & JF870930 \\
\hline Ablabesmyia monilis & Norway & Male adult & Finnmark721 & 136814 & JN286021 \\
\hline Ablabesmyia monilis & Norway & Male adult & NO 104 & 200861 & MK403758 \\
\hline Ablabesmyia monilis & Norway & Female adult & NO 92 & 200850 & MK403743 \\
\hline Ablabesmyia monilis & Norway & Male adult & RIN_CH13 & 148138 & MK403765 \\
\hline Ablabesmyia monilis & Norway & Male adult & RIN_CH15 & 148140 & MK403760 \\
\hline Ablabesmyia monilis & Norway & Male adult & RIN_CH29 & 148153 & MK403748 \\
\hline Ablabesmyia monilis & Norway & Larva & RIN_CH30 & 148154 & MK403741 \\
\hline Ablabesmyia monilis & Norway & Larva & RIN_CH32 & 148156 & MK403754 \\
\hline Ablabesmyia monilis & Norway & Larva & RIN_CH34 & 148158 & MK403764 \\
\hline Ablabesmyia monilis & Norway & Larva & RIN_CH50 & 148174 & MK403759 \\
\hline Ablabesmyia monilis & Norway & Male adult & SOE10 & 124308 & HQ105016 \\
\hline Ablabesmyia monilis & Norway & Male adult & SOE9 & 124307 & HQ105017 \\
\hline Ablabesmyia monilis & Norway & Male adult & TRD-CH158 & 200150 & MK403761 \\
\hline Ablabesmyia monilis & Norway & Female adult & TRD-CH221 & 200211 & MK403750 \\
\hline Ablabesmyia monilis & Norway & Male adult & TRD-CH292 & 200278 & MK403763 \\
\hline Ablabesmyia monilis & Norway & Male adult & TRD-CH308 & 200294 & MK403762 \\
\hline Ablabesmyia monilis & Norway & Female adult & TRD-CH309 & 200295 & MK403751 \\
\hline Ablabesmyia monilis & Norway & Male adult & TRD-CH325 & 200310 & MK403742 \\
\hline Ablabesmyia monilis & Norway & Male pupa & TRD-CH427 & 200410 & MK403745 \\
\hline Ablabesmyia monilis & Norway & Female adult & TRD-CH8 & 148261 & MK403746 \\
\hline
\end{tabular}

DNA extraction and amplification followed standard protocols at the CCDB and used the primers LepF1 + LepR1 [38], or a cocktail of the Lep and Folmer, et al. [39] primers (C_LepFolF + C_LepFolR) [40]. 
Polymerase chain reaction (PCR) products were purified for bidirectional sequencing with BigDye 3.1 termination (Applied Biosystems, Foster City, CA, USA) at the CCDB. Alignments were implemented on amino acid sequences, and refined using the Muscle algorithm in MEGA X [41], and were trivial, since no indels were present. Only sequences $>300 \mathrm{bp}$ were included in the final alignment.

Maximum likelihood (ML) tree searches were performed using the Tamura 3-parameter with gamma correction for rate heterogeneity $(\mathrm{T} 92+\mathrm{G})$. This model was determined to be the most suitable model of nucleotide substitution for our dataset using the hierarchical likelihood ratio test in MEGA X. Bootstrap analyses were conducted with 1000 pseudoreplicates [42]. Neighbor-joining tree searches and analyses of intra- and interspecific genetic divergences were conducted using the Kimura-2-parameter (K2P) model [43] for easier comparison with most published DNA barcode investigations. We used Ablabesmyia aspera (Roback, 1959) and A. longistyla Fittkau, 1962 as outgroups in the analysis, and rooted the resulting tree with $A$. longistyla, as this species is morphologically most divergent from A. monilis sensu lato. The Barcode Index Numbers [44] equivalent to genetic clusters in our resultant tree were analyzed in BOLD to investigate the documented distribution of each genetic lineage.

\section{Results}

Mitochondrial DNA COI (mtDNA COI) sequences were recovered from 56 specimens of four Ablabesmyia species (Table 1). Most of the aligned sequences were 658 base pairs long $(94.6 \%)$ with 164 variable sites $(24.9 \%)$, and included 137 sites $(83.5 \%)$ being possibly parsimony informative. The majority of the variable sites were in the third codon-position (Table 2). The sequences were highly AT-biased, particularly in the third position, with a combined average AT-composition of $89.2 \%$ (Table 2). A hierarchical likelihood ratio test of aligned sequences in MEGA $X$ returned the Tamura 3-parameter with the gamma correction for rate heterogeneity $(\mathrm{T} 92+\mathrm{G})$ as the best model $(-\operatorname{lnL}=2435.952, \mathrm{BIC}=6045.744, \mathrm{AIC}=5096.616)$.

Table 2. Variable and informative sites, and average nucleotide composition in the aligned COI gene sequences.

\begin{tabular}{ccccccccc}
\hline $\begin{array}{c}\text { Nucleotide } \\
\text { Position }\end{array}$ & $\begin{array}{c}\text { Variable } \\
\text { Sites (\%) }\end{array}$ & $\begin{array}{c}\text { Informative } \\
\text { Sites (\%) }\end{array}$ & T (\%) & C (\%) & A (\%) & G (\%) & AT (\%) & GC (\%) \\
\hline 1st & 15.2 & 13.9 & 27.2 & 16 & 26.4 & 30.4 & 53.6 & 46.4 \\
2nd & 1.9 & 0.0 & 43 & 27.4 & 13.6 & 16 & 56.6 & 43.4 \\
3rd & 82.9 & 86.1 & 47 & 8.4 & 42.2 & 2.4 & 89.2 & 10.8 \\
All & $24.9 \%$ & $83.5 \%$ & 39.1 & 17.3 & 27.4 & 16.2 & 66.5 & 33.5 \\
\hline
\end{tabular}

Average intra- and interspecific K2P-distances for the examined Ablabesmyia species were 3.7\% and $12.5 \%$, respectively (Table 3$)$. Maximum intraspecific divergence was found in A. aspera $(8.0 \%)$. The lowest interspecific divergences were observed between Ablabesmyia americana and A. monilis (average 10.0\%). Intraspecific and interspecific distances generated by the ML model yielded similar results (data not shown). There were no identical mtDNA COI sequences between species, and all species were distinguishable by genetic deviation and character state variances (Figure 1).

Table 3. Intra- and interspecific Kimura 2-parameter distances between Ablabesmyia species defined by morphology. N/A denotes species with only one specimen analyzed.

\begin{tabular}{ccccc}
\hline Species & $\begin{array}{c}\text { Average } \\
\text { Intraspecific } \\
\text { K2-P Divergence }\end{array}$ & $\begin{array}{c}\text { Maximum } \\
\text { Intraspecific } \\
\text { K2-P Divergence }\end{array}$ & $\begin{array}{c}\text { K2-P Divergence } \\
\text { to Nearest } \\
\text { Neighbor }\end{array}$ & $\begin{array}{c}\text { Average } \\
\text { Interspecific } \\
\text { K2-P Divergence }\end{array}$ \\
\hline Ablabesmyia aspera & $3.7 \%$ & $8.0 \%$ & $10.8 \%$ & $12.6 \%$ \\
Ablabesmyia americana & $0.6 \%$ & $1.3 \%$ & $10.0 \%$ & $11.9 \%$ \\
Ablabesmyia longistyla & $\mathrm{N} / \mathrm{A}$ & $\mathrm{N} / \mathrm{A}$ & $14.4 \%$ & $16.2 \%$ \\
Ablabesmyia monilis & $4.2 \%$ & $8.6 \%$ & $10.0 \%$ & $12.5 \%$ \\
\hline
\end{tabular}




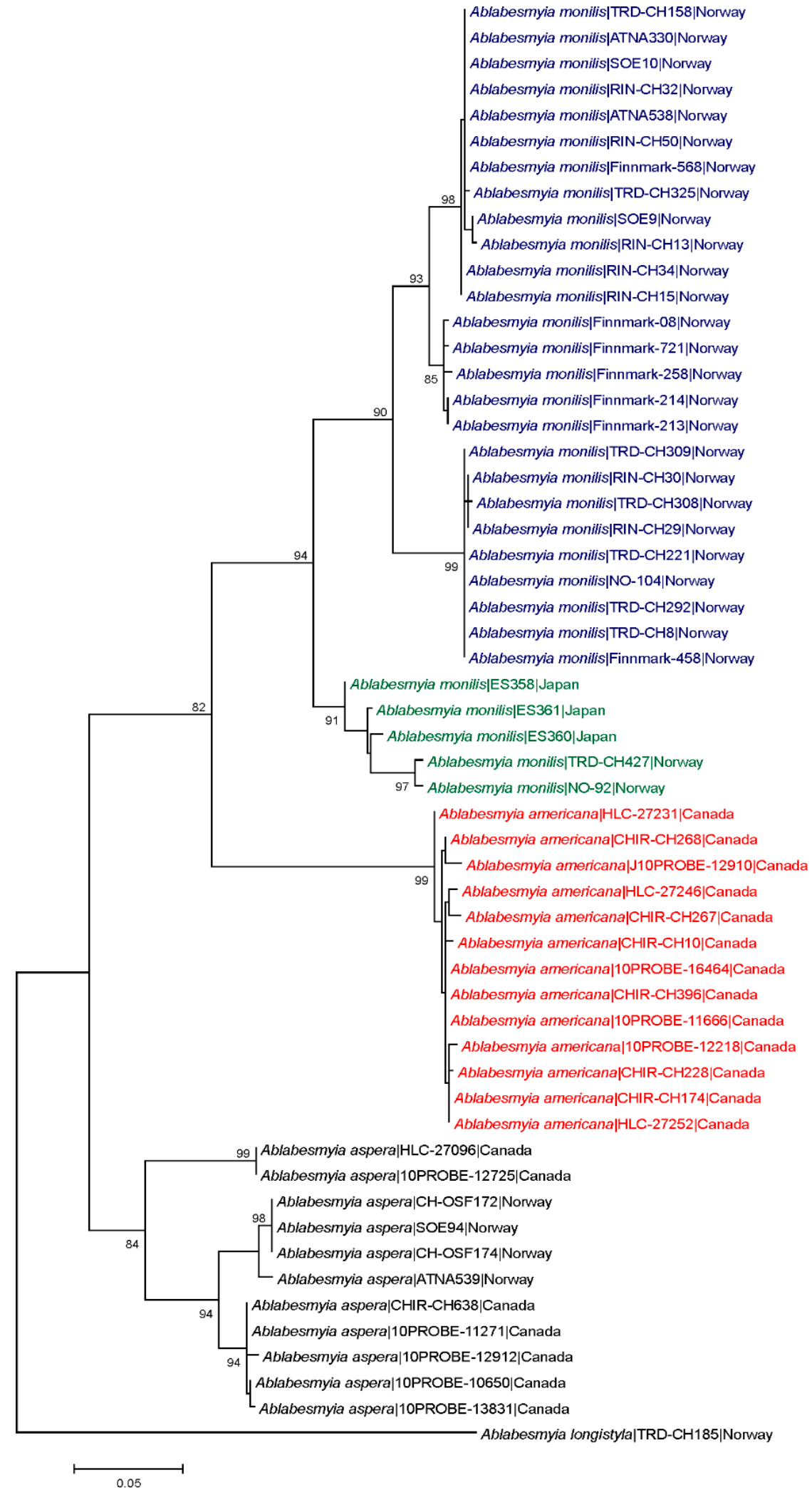

Figure 1. Maximum likelihood (ML) tree for species of Ablabesmyia, based on partial COI sequences (DNA barcodes) and using the Tamura 3-parameter model with gamma correction for rate heterogeneity. Numbers on branches are bootstrap values $>80 \%$. 
The ML tree shows large barcode divergence between all sampled Ablabesmyia species. Ablabesmyia americana and A. monilis comprised well-supported monophyletic clusters, completely concurring with the morphological identifications (Figure 1). For comparison, a Neighbor-joining tree was also generated using the K2P model, and produced identical trees (data not shown). Bootstrap support showed minor deviation between analyses, but were always 90\% or higher for all species groups, except for the principal Ablabesmyia aspera group, which was endorsed by $84 \%$ of the bootstrap pseudoreplicates in the NJ-analysis. Nucleotide sequences from specimens recognized morphologically as Ablabesmyia americana and A. monilis differed by a minimum of $10.0 \%$. The adult male of Ablabesmyia americana presents a shorter, less curved aedeagal blade, and slightly weaker, inferior volsella in the male hypopygium (Figure $2 \mathrm{~A}, \mathrm{~B}$ ), whereas $A$. monilis exhibits a longer, more strongly curved dorsal lobe, and more conspicuous inferior volsella. Regarding adult females, Ablabesmyia americana has less than one-fourth dark sclerotized seminal capsules as opposed to about one-half to two-thirds sclerotization in A. monilis (Figure 2C,D).
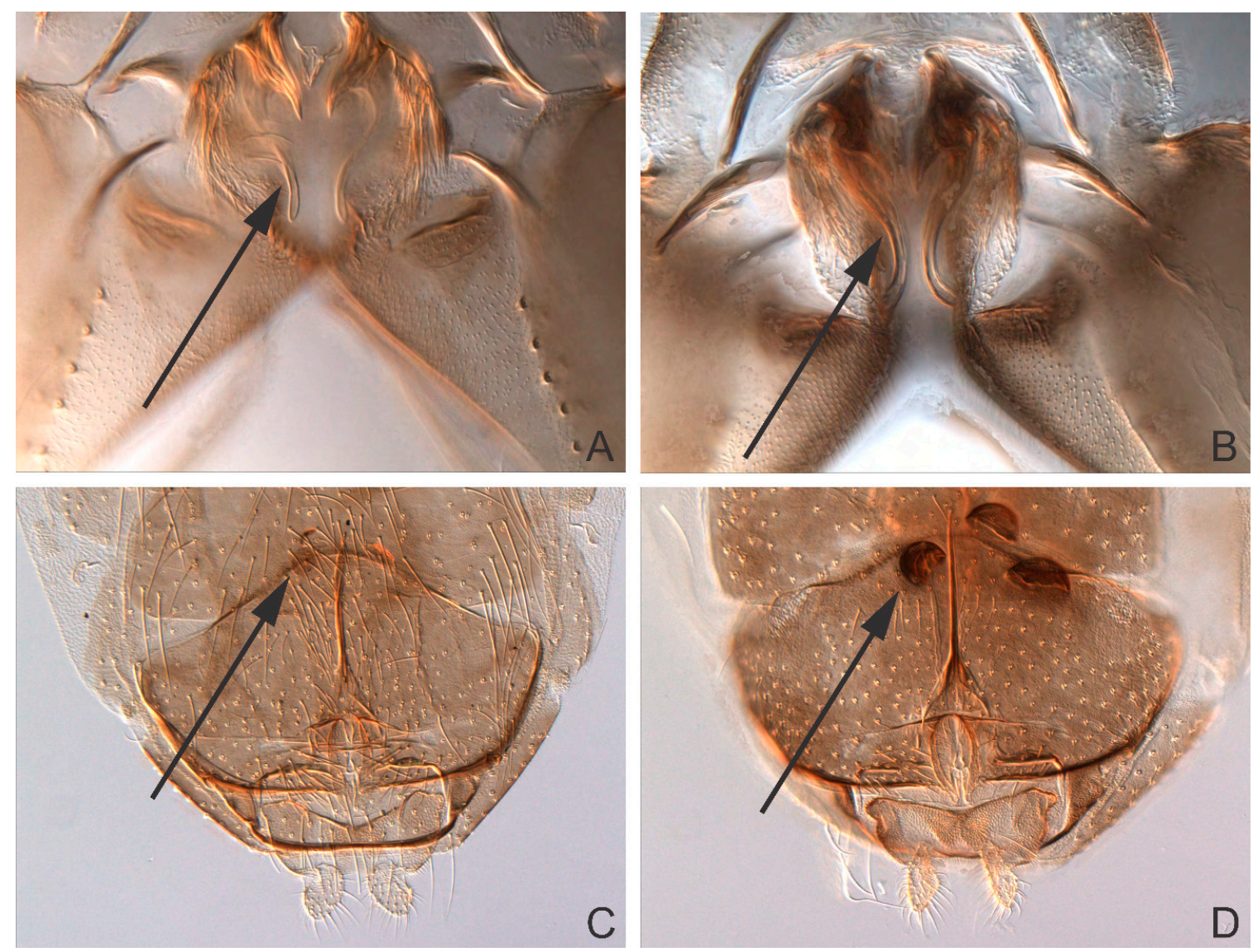

Figure 2. Male. (A) Ablabesmyia americana,(B) Ablabesmyia monilis: Aedeagal blade. Female. (C) Ablabesmyia americana, (D) Ablabesmyia monilis: Seminal capsules.

The specimens determined as Ablabesmyia monilis by morphology build at least two distinct barcode clusters (Figure 1). However, we found no evident morphological characters that aid separation the species in these groups. Specimens of Ablabesmyia monilis were collected in Japan and Norway (Table 1, Figure 1), but one of the clusters (BIN BOLD:ABY9333) includes 327 records from eastern and western Canada in BOLD. Finally, specimens of Ablabesmyia aspera, used as an outgroup in our analysis, were grouped into three separate barcode clusters (BINs BOLD:AAF3626, BOLD:AAF3627, BOLD:AAF3638). Specimens of Ablabesmyia aspera of these three clusters were collected in Canada and Norway (Table 1), and exhibited a clear geographical structuring of genetic diversity across the distribution range, with one of the group composed only by species from Norway (BIN BOLD:AAF3626). 


\section{Taxonomy}

Ablabesmyia americana Fittkau, 1962

Ablabesmyia americana Fittkau, 1962: 430 [20] (proposed new name for A. monilis Johannsen nec Linnaeus).

Ablabesmyia americana Sublette and Sublette, 1965: 148 [45] (taxonomic placement).

Ablabesmyia americana Roback, 1971: 375 [25] (proposed junior synonym of Ablabesmyia monilis Linnaeus).

Material examined. Type material: Lectotype (designated here, CUIC): Adult male with pupal and larval exuviae, USA, New York, Ithaca, Cascadilla Pond, 28.vii.1902, O.A.J. Lot 1507. 1 Paralectotype: Female with pupal and larval exuviae (CUIC), as previous except for Cascadilla Creek, 30.vii.1902, O.A.J. Lot 1508.

Additional material: Adult female (Specimen ID: HLC-27246, NTNU-VM 201786), CANADA,

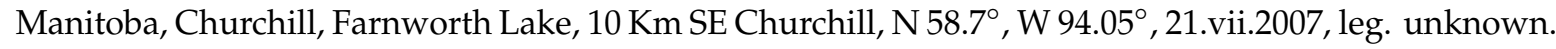
Adult female (Specimen ID: CHIR_CH268, NTNU-VM 201781), as previous except for Ramsey Creek, Malaise trap, N 58.73054 , W 93.78007 ${ }^{\circ}, 13 \mathrm{~m}$ a.s.l., 15-17.vii.2006, leg. T. Ekrem and E. Stur. Larva (Specimen ID: BIOG03304-G12, CBG), as previous except for Ontario, Algonquin Provincial Park, stream by Leaf Lake Sign, Drainage stream in swamp, N 45.5517 , W $78.2696^{\circ}, 350$ m a.s.l., 26.vi.2011. leg. G. Martin and O. Zaheer. Larva (Specimen ID: BIOG01725-B09) as previous.

Diagnostic characters. Ablabesmyia americana differs from Ablabesmyia monilis by the following characters. Adult male: Hypopygium with short, moderately curved aedeagal blade and inconspicuous inferior volsella. Adult female: Genitalia with seminal capsules less than one-fourth dark sclerotized. Immature stages: Indistinguishable from most of the described species of Ablabesmyia.

Adult female ( $n=2$, except where otherwise stated)

Size. Total length $2.83-3.04 \mathrm{~mm}$. Wing length $2.3-3.0 \mathrm{~mm}$. Total length/wing length 1.09-1.24. Wing length/profemur length 2.72-2.93.

General coloration. Head pale brown with darker occipital margin; pedicel and antenna brown; maxillary palp pale brown. Thorax pale brown. Wing membrane transparent with dark spots. Femur with one brown band, tibia with three brown bands. Abdominal tergites and genitalia brown.

Head. Temporal setae 20-26, irregularly multiserial. Eye ratio 1.60-1.99. Tentorium 188-221 $\mu \mathrm{m}$ long. Clypeus 157-163 $\mu \mathrm{m}$ long, 96-111 $\mu \mathrm{m}$ wide at largest part, bearing 30-32 setae. Cibarial pump 353-372 $\mu \mathrm{m}$ long. Lengths of palpomeres 1-5 (in $\mu \mathrm{m}$ ): 65-68; 125-146; 175-198; 120-150; 212 (1). Antenna 690 (1) $\mu \mathrm{m}$ long, diameter of pedicel 98 (1) $\mu \mathrm{m}$. AR 0.43 (1).

Thorax. Antepronotals 7-8. Acrostichals 70-86, double staggered row which diverges posteriorly to join the dorsocentral row of setae; dorsocentrals 58-64, biserial anteriorly and uniserial posteriorly; prealars 32-44; supraalar 2. Anapleural suture ratio 0.65 (1). Scutellum with transverse row of 20-24 setae and group of numerous fine anterior setae. Scutal tubercle indistinct.

Wing. Width 0.81-0.96 mm. Costa 2.1-2.4 mm long. VR 0.86-0.94. WW 0.36-0.37. Brachiolum with 3-4 setae. Squama with 38-42 setae.

Legs. Foreleg: Width at apex of tibia $66-70 \mu \mathrm{m}$, tibia with single, apical and pectinate spur 50 (1) $\mu \mathrm{m}$ long, with 9 (1) lateral teeth; ta ${ }_{1-3}$ with preapical pseudospurs. Mid leg: Width at apex of tibia 67-70 $\mu \mathrm{m}$, tibia with two apical spurs 36-37; 61-67 $\mu \mathrm{m}$ long, with 4-6 lateral teeth; ta ${ }_{1-3}$ with preapical pseudospurs. Hind leg: Width at apex of tibia 65-71 $\mu \mathrm{m}$, tibia with two apical spurs 33-36; $70-71 \mu \mathrm{m}$ long, with 3-6 lateral teeth; comb not indistinct; $\mathrm{ta}_{1-3}$ with preapical pseudospurs. Claws slender, distally recurved and pointed and with large basal protuberance. Lengths and proportion of leg segments as in Table 4.

Genitalia (Figure 2C). Gonapophysis VIII elongated, 119-122 $\mu \mathrm{m}$ long. Coxosternapodeme 91-102 $\mu \mathrm{m}$ long. Postgenital plate broadly rounded. Cerci oval-quadrate, 73 (1) $\mu \mathrm{m}$ long, 58 (1) $\mu \mathrm{m}$ wide, with 18-24 elongated setae. Labia with inconspicuous microtrichia. Notum 177-179 $\mu \mathrm{m}$ long. Seminal capsules oblong, 56-58 $\mu \mathrm{m}$ long, 51 (1) $\mu \mathrm{m}$ wide, less than one-fourth dark sclerotized, with conical-shaped necks. Length ratio SCa/No 0.31-0.32. 
Table 4. Lengths (in $\mu \mathrm{m}$ ) and proportions of leg segments in Ablabesmyia americana Fittkau, female $(\mathrm{n}=1-2)$.

\begin{tabular}{cccccc}
\hline Leg Position & $\mathbf{f e}$ & $\mathbf{t i}$ & $\mathbf{t a}_{\mathbf{1}}$ & $\mathbf{t a}_{\mathbf{2}}$ & $\mathbf{t a}_{\mathbf{3}}$ \\
\hline $\mathrm{p}_{1}$ & 837 & 924 & 743 & 450 & 329 \\
$\mathrm{p}_{2}$ & $985-1126$ & $982-1125$ & 778 & 508 & 329 \\
$\mathrm{p}_{3}$ & $898-1075$ & $1226-1381$ & 1137 & 657 & 473 \\
\hline Leg Position & $\mathbf{t a}_{\mathbf{4}}$ & $\mathbf{t a}_{\mathbf{5}}$ & $\mathbf{L R}$ & $\mathbf{B V}$ & $\mathbf{S V}$ \\
\hline $\mathrm{p}_{1}$ & 229 & 153 & 0.80 & 2.15 & 2.37 \\
$\mathrm{p}_{2}$ & 227 & 168 & 0.69 & 2.46 & 2.89 \\
$\mathrm{p}_{3}$ & 291 & 181 & 0.82 & 2.24 & 2.16 \\
\hline
\end{tabular}

Pupa ( $n=2$, except where otherwise stated)

Size. Abdomen 3.6-3.8 mm long in male.

General coloration. Exuviae (pupal skins) mostly pale brown without any distinctive pattern; thoracic horn brown.

Cephalothorax (Figure 3A). Wing sheath smooth, 1.2-1.3 mm long. Thoracic horn 441-450 $\mu \mathrm{m}$ long and 223-238 $\mu \mathrm{m}$ wide (Figure 3A). THR 1.98-1.89. Respiratory atrium filling the lumen cavity, reticulation of respiratory atrium indistinct, lumen homogeneous, preapical papilla and plastron plate absent, aeropyle tube sinuate with single membranous lobe. External membrane with few spinules basally interconnected, forming scales. Basal lobe covered with small spinules. Thoracic comb with 11-13 conical tubercles (Figure 3A).

Abdomen (Figure 3B-D). Tergite I with scar 201-210 $\mu \mathrm{m}$ long. Shagreen on tergites serially arranged in groups of 2-4 (Figure 3B), evenly distributed. Sternites I and II with sparse shagreen. Abdominal chaetotaxy as in Figure 3C. Abdominal segment VII with 4 LS-setae. A VIII with 5 LS-setae. Anal lobe 496-523 $\mu \mathrm{m}$ long, 383-387 $\mu \mathrm{m}$ wide (Figure 3D). ALR 1.28-1.36. Male genital sac not surpassing apex of anal lobe.

4th instar larva ( $n=4$, except where otherwise stated)

General coloration. Head yellow, postoccipital margin brown. Ligula pale yellow, with apex brown. Abdomen pale yellow. Procercus pale brown along anterior margin.

Head (Figure 4A). Length 787-899 $\mu \mathrm{m}, 422-519 \mu \mathrm{m}$ wide; IC 0.51-0.59. Dorsally DP present, S5 and S8 postero-mesal to S7. Ventrally S9, S10 and SSm forming a right angle (Figure 4A).

Antenna (Figure 4B). Length 405-483 (3) $\mu \mathrm{m}, \mathrm{A}_{1} 346-410 \mu \mathrm{m}$ long, with ring organ located 0.51-0.62 from base, $A_{2} 54-63$ (3) $\mu \mathrm{m}$ long. Peg sensilla very small. Blade and accessory blade extending somewhat beyond flagellum. AR 5.22-5.82.

Maxilla (Figure 4C). Maxillary palp with three segments, palpomere three reduced; palpomeres 1-2: 61-78; 44-46 um long; palpal formula 1+2; $\mathrm{P}_{1} / \mathrm{P}_{2} 1.41-1.69$ (3); $\mathrm{A}_{1} / \mathrm{P}_{1} 4.98-6.14$ (3); $\mathrm{A}_{2} / \mathrm{P}_{1} 0.79-0.81$. Ring organ located between palpomere 1 and 2.

Mandible (Figure 4D). Length 131-139 $\mu \mathrm{m}$. Large, bluntly rounded inner tooth, partly overlying seta subdentalis. Sensillum campaniformium located 0.68-079 from apex. AMD 2.48-3.08.

Mentum and $M$ appendage. Dorsomentum sclerotized, without teeth. Labial vesicles oblong. Pseudoradula with fine granulation, not arranged in distinct longitudinal rows, 131 (3) $\mu \mathrm{m}$ long.

Hypopharyngeal complex (Figure 4E,F). Ligula with 5 teeth, 86-122 $\mu \mathrm{m}$ long, 44-56 $\mu \mathrm{m}$ wide at base; row of teeth concave, middle and inner teeth smaller in size, outer larger; inner teeth slightly curved outward (Figure 4E). IO 15-22, MO 17-21. Paraligula bifid, 45-52 (3) $\mu \mathrm{m}$ long, inner tooth 26-33 (3) $\mu \mathrm{m}$ long. Pecten hypopharyngis with 15-20 subequal teeth, corner tooth and middle teeth slightly broader than remainder (Figure $4 \mathrm{~F}$ ).

Body (Figure 4G). Without fringe of swim-setae. Procercus 96-132 (3) $\mu \mathrm{m}$ long, 31-44 (3) $\mu \mathrm{m}$ wide, with 7 anal setae 594-740 (3) $\mu \mathrm{m}$ long. L/W 2.86-3.19 (3). Anal tubules slender, 230 (1) $\mu \mathrm{m}$ long. Posterior parapod 391-456 $\mu \mathrm{m}$ long. Claws simple (Figure 4G), some with small spines on inner and/or outer margin, 2 of smaller claws dark brown.

Ablabesmyia monilis (Linnaeus, 1758) 
Tipula monilis Linnaeus 1758: 587 [46] (description of adults).

Ablabesmyia monilis Johannsen 1905: 142 [15] (description of adults and immature stages).

Pentaneura monilis Tokunaga 1937: 44 [15] (description of adults).

Ablabesmyia monilis: Fittkau 1962: 437 [20] (description of adults and immature stages).

Ablabesmyia monilis Roback 1971: 375 [25] (adult male description).

Material examined. Adult female: (Specimen ID: ATNA330, NTNU-VM 201789), NORWAY, Oppland, Rondane National Park, Skranglehaugen (P2), N 61.98141 ${ }^{\circ}$, E 9.80480 $1119 \mathrm{~m}$ a.s.l., 14-21.vii.2008, leg. T. Ekrem. Adult female: (Specimen ID: NO92, NTNU-VM 200850) as previous except for Trøndelag, Trondheim, Gjeddvatnet, N 63.38272 ${ }^{\circ}$, E 10.60776, 152 m a.s.l. 20.vi.2010, leg. J. K. Skei.
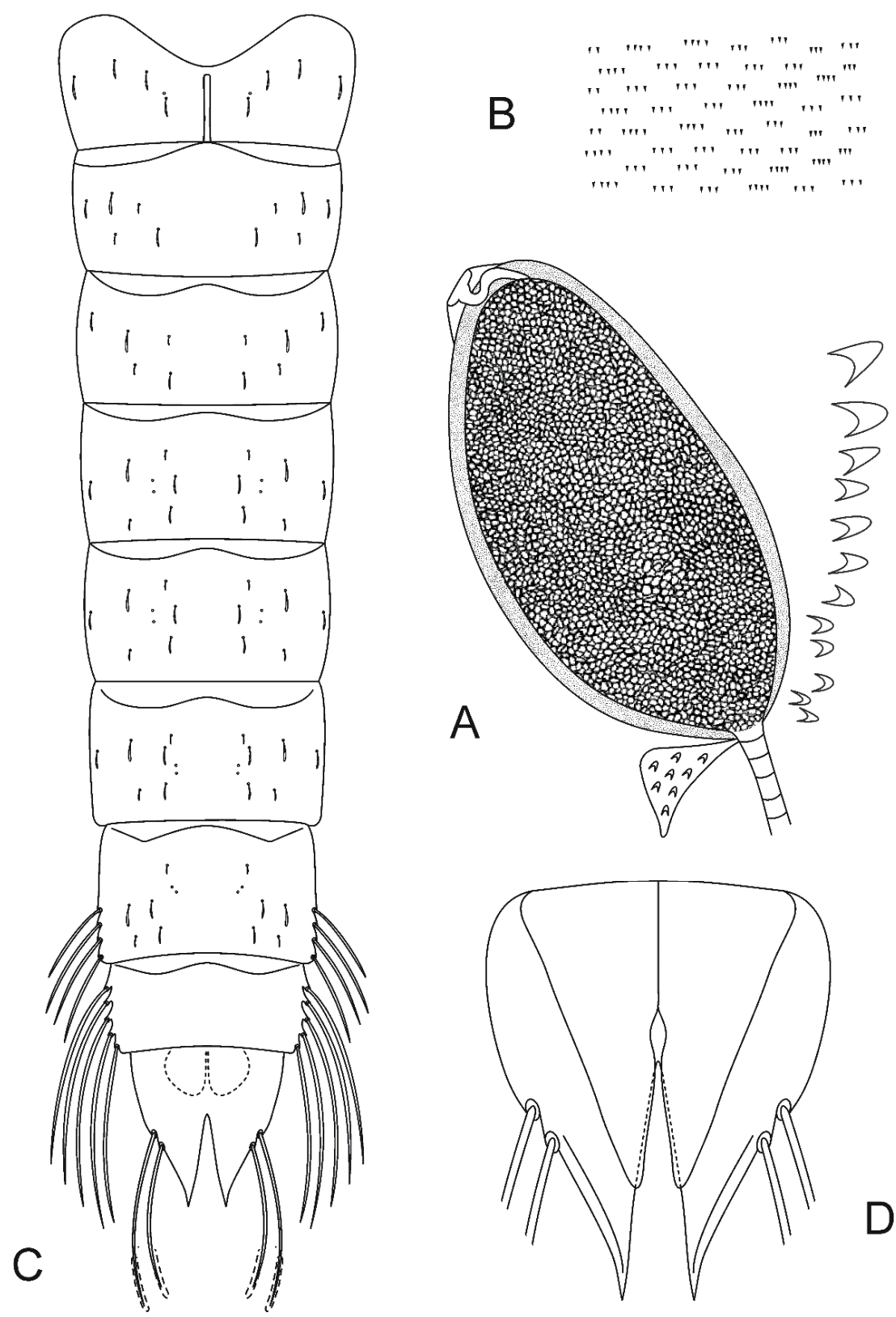

Figure 3. Ablabesmyia americana Fittkau. Pupa: (A) Thoracic horn with basal lobe and thoracic comb. (B) Shagreen on tergites. (C) Female abdominal segments with chaetotaxy, dorsal view. (D) Anal lobe and male genital sac, ventral view. 


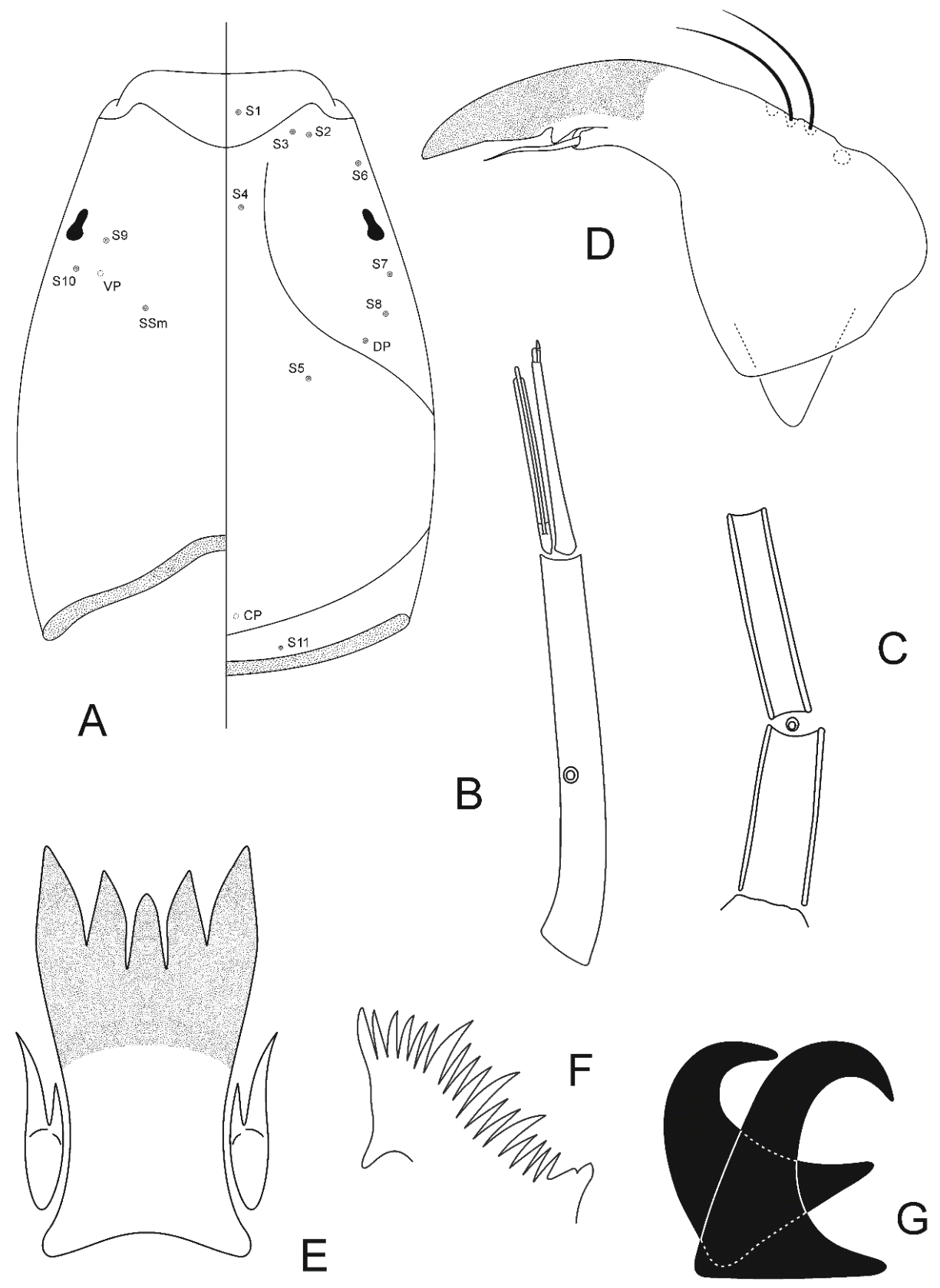

Figure 4. Ablabesmyia americana Fittkau. Larva: (A) Head with chaetotaxy. Left: Ventral view, right: Dorsal view. (B) Antenna. (C) Maxillary palp. (D) Mandible. (E) Ligula and paraligula. (F) Pecten hypopharyngis. (G) Dark claws of posterior parapod.

Adult female ( $n=2$, except where otherwise stated)

Size. Total length $3.63-3.77 \mathrm{~mm}$. Wing length $2.7-3.3 \mathrm{~mm}$. Total length/wing length $1.09-1.40$. Wing length/profemur length 2.93 (1).

General coloration. Head pale brown with darker occipital margin; pedicel and antenna brown; maxillary palp pale brown. Thorax pale brown. Wing membrane transparent with dark spots. Femur with one brown band, tibia with three brown bands. Abdominal tergites and genitalia brown.

Head. Temporal setae 36-40, irregularly multiserial. Eye ratio 1.46-1.56. Tentorium 244-258 $\mu \mathrm{m}$ long. Clypeus 179-183 $\mu \mathrm{m}$ long, $130-139 \mu \mathrm{m}$ wide at largest part, bearing $50-56$ setae. Cibarial pump 381-409 $\mu \mathrm{m}$ long. Lengths of palpomeres $1-5$ (in $\mu \mathrm{m}$ ): 69-74; 141-183; 178-235; 136-150; 258-268. Antenna 722-813 $\mu \mathrm{m}$ long, diameter of pedicel 103-106 $\mu \mathrm{m}$. AR 0.40-0.41. 
Thorax. Antepronotals 11-15. Acrostichals 88-96, double staggered row which diverges posteriorly to join the dorsocentral row of setae; dorsocentrals 82-92, biserial anteriorly and uniserial posteriorly; prealars 36-50; supraalar 2. Anapleural suture ratio 0.65-0.67. Scutellum with transverse row of 18-22 setae and group of numerous fine anterior setae. Scutal tubercle indistinct.

Wing. Width 0.98-1.14 mm. Costa 2.6-3.3 mm long. VR 0.87-0.91. WW 0.34-0.37. Brachiolum with 2-3 setae. Squama with $46-78$ setae.

Legs. Foreleg: Width at apex of tibia 91 (1) $\mu \mathrm{m}$, tibia with single, apical and pectinate spur 72 (1) $\mu \mathrm{m}$ long, with 7 (1) lateral teeth; ta $\mathrm{t}_{1-3}$ with preapical pseudospurs. Mid leg: Width at apex of tibia 71-86 $\mu \mathrm{m}$, tibia with two apical spurs 33-44; 68-93 $\mu \mathrm{m}$ long, with 4-6 lateral teeth; ta ${ }_{1-3}$ with preapical pseudospurs. Hind leg: Width at apex of tibia 65-93 $\mu \mathrm{m}$, tibia with two apical spurs 44-47; 75-90 $\mu \mathrm{m}$ long, with 4-6 lateral teeth; comb not indistinct; $\mathrm{ta}_{1-3}$ with preapical pseudospurs. Claws slender, distally recurved and pointed and with large basal protuberance. Lengths and proportion of leg segments as in Table 5.

Genitalia (Figure 2D). Gonapophysis VIII elongated, 118-130 $\mu \mathrm{m}$ long. Coxosternapodeme $110-111 \mu \mathrm{m}$ long. Postgenital plate broadly rounded. Cerci oval-quadrate, $68-73 \mu \mathrm{m}$ long, $62-63 \mu \mathrm{m}$ wide, with 20-24 elongated setae. Labia with inconspicuous microtrichia. Notum 202-206 $\mu \mathrm{m}$ long. Seminal capsules oblong, 82-83 $\mu \mathrm{m}$ long, 60-61 $\mu \mathrm{m}$ wide, one-half to two-thirds sclerotized, with conical-shaped necks. Length ratio SCa/No 0.40-0.41.

Table 5. Lengths (in $\mu \mathrm{m}$ ) and proportions of leg segments for Ablabesmyia monilis (Linnaeus, 1758) $(\mathrm{n}=1-2)$.

\begin{tabular}{cccccc}
\hline Leg Position & Fe & $\mathbf{t i}$ & $\mathbf{t a}_{\mathbf{1}}$ & $\mathbf{t a}_{\mathbf{2}}$ & $\mathbf{t a}_{\mathbf{3}}$ \\
\hline $\mathrm{p}_{1}$ & 1134 & 1383 & 1079 & 661 & 480 \\
$\mathrm{p}_{2}$ & $1114-1397$ & $887-1413$ & $556-1028$ & $557-626$ & $386-456$ \\
$\mathrm{p}_{3}$ & $1163-1174$ & $1177-1246$ & $876-1492$ & $500-908$ & $341-637$ \\
\hline Leg Position & $\mathbf{t a}_{\mathbf{4}}$ & $\mathbf{t a}_{\mathbf{5}}$ & $\mathbf{L R}$ & $\mathbf{B V}$ & $\mathbf{S V}$ \\
\hline $\mathrm{p}_{1}$ & 307 & 210 & 0.78 & 2.17 & 2.33 \\
$\mathrm{p}_{2}$ & $261-297$ & $177-196$ & $0.63-0.73$ & $1.85-2.44$ & $2.73-3.60$ \\
$\mathrm{p}_{3}$ & $230-380$ & $153-224$ & $0.74-1.20$ & $1.82-2.63$ & $1.62-2.67$ \\
\hline
\end{tabular}

\section{Discussion}

The analysis of partial COI sequences supports the separate species status of Ablabesmyia americana and A. monilis. Moreover, we could associate the species A. aspera and A. longistyla to molecular markers. The ML tree revealed that the majority of the analyzed species are distinctly separated by mtDNA COI sequences, and there are indications of morphologically cryptic lineages within A. monilis and A. aspera.

The presence of a barcode gap is a key concept in DNA barcoding [47]. When the amount of intraspecific genetic divergence is substantially smaller than the amount of interspecific genetic divergence, a barcode gap exists [48]. In our study, the pairwise interspecific genetic distances in the sampled Ablabesmyia species were clearly higher than the intraspecific divergences, demonstrating a barcode gap.

The average K2P distance values found for conspecific comparisons (3.7\%) was discordant from those found in the literature, which range from $0.1 \%$ to $0.8 \%$ [49]. However, this disparity can be a result of cryptic diversity among our sampled species (see below). The mean cutoff value for species delimitation is likely higher in Chironomidae than in many other insect groups, and previous studies have found that morphological species fit poorly with Barcode Index Numbers [50]. For example, Lin, Stur and Ekrem [6] suggest a $4-5 \%$ threshold for genetically separate species of Tanytarsus (Chironominae), while Song, et al. [51] considered a 5-8\% cutoff appropriate to discriminate species of Polypedilum (Chironominae). Herein, we refrain from suggesting an average threshold to delineate the species of Ablabesmyia. Yet any cutoff should be used with caution, since unusual deep intraspecific divergences can indicate cryptic species. Broader sampling throughout the distribution range of $A$. monilis would provide valuable data for the further analysis of the species boundary for this species. Nevertheless, 
data currently in BOLD shows that one genetic lineage of A. monilis sensu stricto (BOLD:ABY9333) is widely distributed in western Canada. Other BINs within A. monilis have records from Europe (BOLD:AAU0774, BOLD:AAF3633), Japan (BOLD:ADB8891), and central Norway (BOLD:ACE5418).

Ablabesmyia moniliformis was established by Fittkau [20] on the basis of Japanese species treated as Pentaneura monilis (Linnaeus, 1758) by Tokunaga [52], which he considered different from the European species [53]. However, Fittkau proposed this new name without providing a diagnostic description, neither made he reference to one, nor designated a holotype. Yet the proposed name satisfies the provisions of Article 13.1.2 of the International Code of Zoological Nomenclature, and the name is available and considered a nomen dubium [29]. Moreover, it seems that the Pentaneura monilis Tokunaga [52] type series may, in fact, comprises two or perhaps three species, including Ablabesmyia monilis, A. prorasha Kobayashi and Kubota, 2002 and A. jogancornua Sasa and Okazawa, 1991 [29]. Furthermore, Tokunaga [52] did not describe nor illustrate the form of the aedeagal complex, a crucial feature for the diagnosis of the Ablabesmyia species. This has prevented the identification of these species unequivocally, and is likely the reasons that the name moniliformis has been overlooked (or disregarded) by Japanese peers [53]. Based on our results, there is evidence supporting a separate cluster of $A$. monilis including records from Japan and Norway. This could represent one of the species in Tokunaga's Ablabesmyia monilis specimens, and thus A. moniliformis. However, no morphological differences could be determined between these two barcode clusters. In addition, the material used by Tokunaga [52], deposited in the Kyushu University Museum, is deteriorated by the long-term storage in alcohol [29]. This prevents the comparison of our material with the Ablabesmyia moniliformis type series. The observed pattern could also be explained by the restricted geographical sampling of $A$. monilis throughout its distributional range. Therefore, additional material is needed to understand the variation between the specimens of $A$. monilis and closely-related species throughout their current distribution. Lastly, the female of Ablabesmyia alba, described by Chaudhuri, et al. [54] for India, resembles A. monilis by having seminal capsules with about one half to two thirds dark sclerotized, and may not be readily separable from this species. Further investigations using molecular data and morphological characters from all life stages will likely reveal the relationship of $A$. alba with $A$. monilis.

In addition to the divergences observed within $A$. monilis, there are two well-separated genetic lineages of A. aspera in Canada (BOLD:AAF3627 and BOLD:AAF3628), and a slightly divergent group with Norwegian specimens (BOLD:AAF3626), indicating cryptic species or divergence caused by geographical isolation in this group. Ablabesmyia aspera belongs to the monilis group sensu Roback, [19] and can be distinguished from all the species of that group by the longer, heavier aedeagal blades and the dorso-mesally approximated dorsal lobes, in natural position [19]. The species is widely distributed in Canada and the United States [25]. In Europe, Ablabesmyia aspera is only recorded from Norway [55].

DNA-aided species determination has become regular practice in various fields of study, including agriculture [56], bioengineering [57] and conservation biology [58]. Moreover, DNA barcodes are recognized as a powerful tool to separate species in a range of chironomid groups [5,6,10,11,51,59-62]. We found mtDNA COI valuable in exploring sequence diversity and distinguishing morphologically similar species within the genus Ablabesmyia. Furthermore, DNA barcodes indicate further cryptic species in Ablabesmyia, or deep intraspecific divergence caused by geographical isolation. We believe that broader geographical sampling and the inclusion of nuclear genes will strengthen our findings and provide additional evidence for the geographical structuring of genetic lineages in Ablabesmyia.

Author Contributions: Conceptualization, E.S., F.L.d.S. and T.E.; methodology, E.S, F.L.d.S. and T.E.; analysis, E.S., F.L.d.S. and T.E.; data curation, E.S. and T.E.; writing-original draft preparation, F.L.d.S.; writing一review and editing, E.S., F.L.d.S. and T.E.; visualization, E.S., F.L.d.S. and T.E.; project administration, E.S.

Funding: DNA barcode data in this publication were in part generated in collaboration with the Norwegian Barcode of Life Network (NorBOL), funded by the Research Council of Norway and the Norwegian Biodiversity Information Centre. F.L. Silva was supported by fellowships from the São Paulo Research Foundation (FAPESP 2016/07039-8 and 2018/01507-5).

Acknowledgments: Thanks to the team at the Canadian Centre for DNA Barcoding for help with DNA barcode analysis, and to Paul Hebert for initiating the chironomid barcoding of Arctic midges in Churchill through a 
Natural Sciences and Engineering Research Council of Canada (NSERC) Polar Year Grant. Thanks also to James Liebherr at Cornell for providing a loan of Johannsen's original material. The Norwegian Biodiversity Information Centre funded biosurveillance projects through the Norwegian Taxonomy Initiative, from which some of the specimens we analyzed originate. We would also like to thank Bohdan Bilyj and Hiromi Niitsuma for supplying us with specimens from Japan, and Martin Spies for providing us with valuable literature.

Conflicts of Interest: The authors declare no conflict of interest.

\section{References}

1. Hebert, P.; Cywinska, A.; Ball, S.; de Waard, J. Biological identifications through DNA barcodes. Proc. R. Soc. Lond. B 2003, 270, 313-321. [CrossRef] [PubMed]

2. Brodin, Y.; Ejdung, G.; Strandberg, J.; Lyrholm, T. Improving environmental and biodiversity monitoring in the Baltic Sea using DNA barcoding of Chironomidae (Diptera). Mol. Ecol. Resour. 2012, 13, 996-1004. [CrossRef] [PubMed]

3. Ekrem, T.; Willassen, E.; Stur, E. A comprehensive DNA sequence library is essential for identification with DNA barcodes. Mol. Phylogenet. Evol. 2007, 43, 530-542. [CrossRef] [PubMed]

4. Ekrem, T.; Stur, E.; Hebert, P.D.N. Females do count: Documenting Chironomidae (Diptera) species diversity using DNA barcoding. Org. Divers. Evol. 2010, 10, 397-408. [CrossRef]

5. Silva, F.L.D.; Ekrem, T.; Fonseca-Gessner, A.A. DNA barcodes for species delimitation in Chironomidae (Diptera): A case study on the genus Labrundinia. Can. Entomol. 2013, 145, 589-602. [CrossRef]

6. Lin, X.; Stur, E.; Ekrem, T. Exploring genetic divergence in a species-rich insect genus using 2790 DNA barcodes. PLoS ONE 2015, 10, e0138993. [CrossRef] [PubMed]

7. Anderson, A.M.; Stur, E.; Ekrem, T. Molecular and morphological methods reveal cryptic diversity and three new species of Nearctic Micropsectra (Diptera: Chironomidae). Freshw. Sci. 2013, 32, 892-921. [CrossRef]

8. Lin, X.-L.; Stur, E.; Ekrem, T. DNA barcodes and morphology reveal unrecognized species in Chironomidae (Diptera). Insect Syst. Evol. 2018, 49, 329-398. [CrossRef]

9. Carew, M.E.; Pettigrove, V.; Hoffmann, A.A. The utility of DNA markers in classical taxonomy: Using cytochrome oxidase I markers to differentiate Australian Cladopelma (Diptera: Chironomidae) midges. Ann. Ent. Soc. Am. 2005, 98, 587-594. [CrossRef]

10. Stur, E.; Ekrem, T. Exploring unknown life stages of Arctic Tanytarsini (Diptera: Chironomidae) with DNA barcoding. Zootaxa 2011, 2743, 27-39. [CrossRef]

11. Silva, F.L.; Wiedenbrug, S. Integrating DNA barcodes and morphology for species delimitation in the Corynoneura group (Diptera: Chironomidae: Orthocladiinae). Bull. Ent. Res. 2014, 104, 65-78. [CrossRef] [PubMed]

12. Niitsuma, H.; Tang, H. Taxonomic review of Ablabesmyia Johannsen (Diptera: Chironomidae: Tanypodinae) from Oriental China, with descriptions of six new species. Zootaxa 2019, 4564, 248-270. [CrossRef]

13. Oliveira, C.S.N.D.; Silva, M.A.N.D.; Gessner, A.A.F. Neotropical Ablabesmyia Johannsen (Diptera: Chironomidae, Tanypodinae)-Part I. Zootaxa 2013, 3733, 1-123. [CrossRef] [PubMed]

14. Fusari, L.M.; Oliveira, C.S.N.; Hamada, N.; Roque, F.O. New species of Ablabesmyia Johannsen from the Neotropical region: First report of a sponge-dwelling Tanypodinae. Zootaxa 2012, 3239, 43-50. [CrossRef]

15. Johannsen, O.A. Aquatic nematocerous Diptera II. Chironomidae. Bull. N. Y. State Mus. 1905, 86, 77-325.

16. Edwards, F.W. British non-biting midges (Diptera, Chironomidae). Trans. Entomol. Soc. Lond. 1929, 77, $279-430$. [CrossRef]

17. Johannsen, O.A. Revision of the North American Species of the Genus Pentaneura [Tendipedidae: Chironomidae, Diptera]. J. N. Y. Entomol. Soc. 1946, 54, 267-289.

18. Freeman, P. A study of the Chironomidae (Diptera) of Africa south of the Sahara. Part I. Bull. Brit. Mus. Nat. Hist. Ent. 1955, 4, 1-67.

19. Roback, S.S. The Subgenus Ablabesmyia of Pentaneura (Diptera; Tendipedidae; Pelopiinae). Trans. Am. Entomol. Soc. 1959, 85, 113-135.

20. Fittkau, E.J. Die Tanypodinae (Diptera: Chironomidae) (Die Tribus Anatopyggiini, Macropelopiini und Pentaneurini). Abhandlungen zur Larvalsystematik der Insekten 1962, 6, 1-453.

21. Aburaya, F.H.; Callil, C.T. Variação temporal de larvas de Chironomidae (Diptera) no Alto Rio Paraguai Cáceres, Mato Grosso, Brasil. Revista Brasileira de Zoologia 2007, 24, 565-572. [CrossRef] 
22. Silva, F.L.D.; Ruiz, S.S.; Bochini, G.L.; Moreira, D.C. Functional feeding habits of Chironomidae larvae (Insecta, Diptera) in a lotic system from Midwestern region of São Paulo State, Brazil. Pan Am. J. Aquat. Sci. 2008, 3, 135-141.

23. Butakka, C.M.D.M.; Gomes, L.C.; Takeda, A.M. Taxonomic and numeric structure of Chironomidae (Diptera) in different habitats of a Neotropical floodplain. Iheringia Série Zoologia 2014, 104, 314-322. [CrossRef]

24. Mazão, G.R.; Bispo, P.D.C. The influence of physical instream spatial variability on Chironomidae (Diptera) assemblages in Neotropical streams. Limnologica 2016, 60, 1-5. [CrossRef]

25. Roback, S.S. The adults of the subfamily Tanypodinae (Pelopiinae) in North America (Diptera: Chironomidae). Monogr. Acad. Nat. Sci. Philad. 1971, 17,1-410.

26. Silva, F.L.D.; Ekrem, T. Phylogenetic relationships of nonbiting midges in the subfamily Tanypodinae (Diptera: Chironomidae) inferred from morphology. Syst. Ent. 2016, 41, 73-92. [CrossRef]

27. Paggi, A.C.; Suarez, D.A. Ablabesmyia reissi, spec. nov., a new species of Tanypodinae from Rio Negro province, Argentina, with descriptions of the adult female and preimaginal stages (Insecta, Diptera, Chironomidae). Spixiana 2000, 23, 259-266.

28. Oliveira, C.S.N.; Fonseca-Gessner, A.A. New species of Ablabesmyia Johannsen (Diptera, Chironomidae, Tanypodinae) from the Neotropical Region, with description of male adults and immature stages. Revista Brasileira de Zoologia 2006, 23, 740-745. [CrossRef]

29. Niitsuma, H. Revision of the Japanese Ablabesmyia (Diptera: Chironomidae: Tanypodinae), with descriptions of three new species. Zootaxa 2013, 3664, 479-504. [CrossRef] [PubMed]

30. Oliveira, C.S.N.; Fonseca-Gessner, A.A.; Navarro Silvia, M.A. The immature stages of Ablabesmyia (Sartaia) metica Roback, 1983 (Diptera: Chironomidae) with keys to subgenera. Zootaxa 2008, 1808, 61-68. [CrossRef]

31. Silva, F.L.D.; Dantas, G.P.D.S.; Hamada, N. Description of immature stages of Ablabesmyia cordeiroi Neubern, 2013 (Diptera: Chironomidae: Tanypodinae). Acta Amazonica 2019, 49, 118-121. [CrossRef]

32. Epler, J.H. Biosystematics of the genus Dicrotendipes Kieffer, 1913 (Diptera: Chironomidae) of the world. Mem. Am. Entomol. Soc. 1988, 36, 1-214.

33. Sæther, O.A. Glossary of chironomid morphology terminology (Diptera: Chironomidae). Ent. Scand. Supp. 1980, 14, 1-51.

34. Kowalyk, H.E. The larval cephalic setae in the Tanypodinae (Diptera: Chironomidae) and their importance in generic determinations. Can. Entomol. 1985, 117, 67-106. [CrossRef]

35. Silva, F.L.D.; Fonseca-Gessner, A.A.; Ekrem, T. Revision of Labrundinia maculata Roback, 1971, a new junior synonym of L. longipalpis (Goetghebuer, 1921) (Diptera: Chironomidae: Tanypodinae). Aquat. Insects 2011, 33, 293-303. [CrossRef]

36. Da Silva, F.L.; Fonseca-Gessner, A.A.; Ekrem, T. A taxonomic revision of genus Labrundinia Fittkau, 1962 (Diptera: Chironomidae: Tanypodinae). Zootaxa 2014, 3769, 1-185. [CrossRef] [PubMed]

37. Ratnasingham, S.; Hebert, P.D.N. BOLD: The Barcode of Life Data System (www.barcodinglife.org). Mol. Ecol. Notes 2007, 7, 355-364. [CrossRef]

38. Hebert, P.D.N.; Penton, E.H.; Burns, J.M.; Janzen, D.H.; Hallwachs, W. Ten species in one: DNA barcoding reveals cryptic species in the neotropical skipper butterfly Astraptes fulgerator. Proc. Natl. Acad. Sci. USA 2004, 101, 14812-14817. [CrossRef] [PubMed]

39. Folmer, O.; Black, M.; Hoeh, W.; Lutz, R.; Vrijenhoek, R. DNA primers for amplification of mitochondrial cytochrome c oxidase subunit I diverse metazoan invertebrates. Mol. Mar. Biol. Biotech. 1994, 3, $294-299$.

40. Hernández-Triana, L.M.; Prosser, S.W.; Rodríguez-Perez, M.A.; Chaverri, L.G.; Hebert, P.D.N.; Ryan Gregory, T. Recovery of DNA barcodes from blackfly museum specimens (Diptera: Simuliidae) using primer sets that target a variety of sequence lengths. Mol. Ecol. Resour. 2014, 14, 508-518. [CrossRef]

41. Kumar, S.; Stecher, G.; Li, M.; Knyaz, C.; Tamura, K. MEGA X: Molecular Evolutionary Genetics Analysis across Computing Platforms. Mol. Biol. Evol. 2018, 35, 1547-1549. [CrossRef] [PubMed]

42. Felsenstein, J. Confidence limits on phylogenies: An approach using the boostrap. Evolution 1985, 39, 783-791. [CrossRef] [PubMed]

43. Kimura, M. A simple method for estimating evolutionary rates of base substitutions through comparative studies of nucleotide sequences. J. Mol. Evol. 1980, 16, 111-120. [CrossRef] [PubMed]

44. Ratnasingham, S.; Hebert, P.D.N. A DNA-Based Registry for All Animal Species: The Barcode Index Number (BIN) System. PLoS ONE 2013, 8, e66213. [CrossRef] [PubMed] 
45. Sublette, J.E.; Sublette, M.S. Family Chironomidae (Tendipedidae). In A Catalog of the Diptera of America North of Mexico; Stone, A., Sabrosky, C.W., Wirth, W.W., Foote, R.H., Coulson, J.R., Eds.; United States Department of Agriculture: Washington, DC, USA, 1965.

46. Linnaeus, C. Systema Naturæ per Regna Tria Naturæ, Secundum Classses, Ordines, Genera, Species, Cum Characteribus, Differentiis, Synonymis, Locis; Laurentius Salvius: Stockholm, Sweden, 1758.

47. Prie, V.; Puillandre, N.; Bouchet, P. Bad taxonomy can kill: Molecular reevaluation of Unio mancus Lamarck, 1819 (Bivalvia: Unionidae) and its accepted subspecies. Knowl. Manag. Aquat. Ec. 2012, 08. [CrossRef]

48. Meyer, C.P.; Paulay, G. DNA barcoding: Error rates based on comprehensive sampling. PLoS Biol. 2005, 3, e422. [CrossRef]

49. Pereira, L.H.G.; Pazian, M.F.; Hanner, R.; Foresti, F.; Oliveira, C. DNA barcoding reveals hidden diversity in the Neotropical freshwater fish Piabina argentea (Characiformes: Characidae) from the Upper Paraná Basin of Brazil. Mitochondr. DNA 2011, 22, 87-96. [CrossRef]

50. Ekrem, T.; Stur, E.; Orton, M.G.; Adamowicz, S.J. DNA barcode data reveal biogeographic trends in Arctic non-biting midges. Genome 2018, 61, 787-796. [CrossRef]

51. Song, C.; Lin, X.L.; Wang, Q.; Wang, X.H. DNA barcodes successfully delimit morphospecies in a superdiverse insect genus. Zool. SCR 2018, 47, 311-324. [CrossRef]

52. Tokunaga, M. Chironomidae from Japan (Diptera), IX. Tanypodinae and Diamesinae. Philipp. J. Sci. 1937, 62, 21-63.

53. Kobayashi, T.; Kubota, K. A revision of male adult Ablabesmyia (Diptera: Chironomidae: Tanypodinae) from Japan, with a description of A. prorasha, new species, and a key to adult male species of the genus. Raffles Bull. Zool. 2002, 50, 317-326.

54. Chaudhuri, P.K.; Debnath, R.K.; Nandi, S.K. Tanypodine midges of the genus Ablabesmyia Johannsen (Diptera: Chironomidae) from West Bengal with a note on their seasonal incidence and sex ratios. J. Nat. Hist. 1983, 17, 901-917. [CrossRef]

55. Sæther, O.A.; Spies, M. Fauna Europaea: Chironomidae. In Fauna Europaea: Diptera: Nematocera; De Jong, H., Pape, T., Eds.; Fauna Europaea: Berlin, Germany, 2013; Available online: https://fauna-eu.org (accessed on 18 September 2019).

56. Bernet, G.P.; Bramardi, S.; Calvache, D.; Carbonell, E.A.; Asins, M.J. Applicability of molecular markers in the context of protection of new varieties of cucumber. Plant Breed. 2003, 122, 146-152. [CrossRef]

57. Kirchner, O.; Tauch, A. Tools for genetic engineering in the amino acid-producing bacterium Corynebacterium glutamicum. J. Biotechnol. 2003, 104, 287-299. [CrossRef]

58. Kress, W.J.; García-Robledo, C.; Uriarte, M.; Erickson, D.L. DNA barcodes for ecology, evolution, and conservation. Trends Ecol. Evol. 2015, 30, 25-35. [CrossRef] [PubMed]

59. Carew, M.E.; Pettigrove, V.; Cox, R.L.; Hoffmann, A.A. DNA identification of urban Tanytarsini chironomids (Diptera: Chironomidae). J. N. Am. Benth. Soc. 2007, 26, 587-600. [CrossRef]

60. Da Silva, F.L.; Wiedenbrug, S.; Trivinho-Strixino, S.; da Oliveira, C.S.N.; Pepinelli, M. Two new species of Hudsonimyia Roback, 1979 (Diptera: Chironomidae: Tanypodinae) from Neotropical Region unveiled by morphology and DNA barcoding. J. Nat. Hist. 2012, 46, 1615-1638. [CrossRef]

61. Stur, E.; Ekrem, T. A review of Norwegian Gymnometriocnemus (Diptera, Chironomidae) including the description of two new species and a new name for Gymnometriocnemus volitans (Goetghebuer) sensu Brundin. ZooKeys 2015, 508, 127-142. [CrossRef]

62. Song, C.; Wang, Q.; Zhang, R.; Sun, B.; Wang, X. Exploring the utility of DNA barcoding in species delimitation of Polypedilum (Tripodura) non-biting midges (Diptera: Chironomidae). Zootaxa 2016, 4079, 534-550. [CrossRef]

(C) 2019 by the authors. Licensee MDPI, Basel, Switzerland. This article is an open access article distributed under the terms and conditions of the Creative Commons Attribution (CC BY) license (http://creativecommons.org/licenses/by/4.0/). 